Western University

Scholarship@Western

Department of English Publications

English Department

Fall 2003

\title{
Mother Courage and its Abject: Reading the Violence of Identification
}

\author{
Kim Solga \\ University of Toronto
}

Follow this and additional works at: https://ir.lib.uwo.ca/englishpub

Part of the English Language and Literature Commons, and the Theatre and Performance Studies Commons

Citation of this paper:

Solga, Kim, "Mother Courage and its Abject: Reading the Violence of Identification" (2003). Department of English Publications. 4. https://ir.lib.uwo.ca/englishpub/4 


\section{Mother Courage and Its Abject: Reading the Violence of Identification ${ }^{1}$}

\section{Toward an Epic Feminine}

Fifteen years ago, Elin Diamond suggested that feminist theatre theorists could learn a thing or two from Bertolt Brecht and altered the course of an industry. "Brechtian Theory/Feminist Theory: Toward a Gestic Feminist Criticism" (1988; expanded and reprinted in UnMaking Mimesis, 1997) revolutionized the way many of us talk about theatre as Diamond imagined how feminist critics might "re-radical[ize]" (84) such commonplace Brechtian techniques as the "not-but" and the Verfremdungseffekt for our performance theory and practice; her work promptly generated a number of subsequent inquiries into the productive potential of aligning Brecht's theory with contemporary feminist concerns. ${ }^{2}$ Diamond's own rejuvenation was expressly theoretical, never intended to engage the prickly problem of Brecht's own dramas and the "too many saintly mothers" (83) peopling them; reading her work now, across the luxury of distance, this choice comes as no particular surprise. Few feminists writing about theatre in the later 1980s would have chosen Brecht as a source of inspiration: ${ }^{3}$ Diamond's intervention appeared within a critical climate still hostile to his not unproblematic female characterizations as several prominent scholars of his drama, taking a cue from the seminal work of Sara Lennox in the late 1970s, parsed his dramatic treatment of women and found it lacking. ${ }^{4}$ I want to emphasize forcefully that I, a young scholar whose engagement with this critical heritage has only ever been across a luxurious distance, far from the visceral, politicized moment of its production, find these critiques to be both stimulating and essential to a full account of Brecht's work. Yet I am also not fully satisfied by them. Though Diamond's own gestic feminist project 
implicitly allies itself with contemporary critiques of Brecht's dramatic oeuvre as it dismisses the plays as "conventionally gendered" (83), it also invites the question we are now, at a new critical juncture, prepared to tackle: how might we "re-radicalize" the plays as well as the theory as inherently potent loci of materialist gender performance?

My paper offers one response to this question as I read Mother Courage and Her Children (1939) for signs of a material epic feminine by rejuvinating the much-maligned figure of Courage's mute daughter, Kattrin. Though Mother Courage has at times been favoured by feminist critics for its title character's rejection of conventional maternal paradigms, those same critics tend to perceive Kattrin as a kind of revved-up maternal ideal whose hyper-sentimentality about babies and boyfriends wrecks any feminist message the play might have presented. In counterpoint to this argument, I re-cast Kattrin - the play’s silent centre and consequently its object of discursive production - as the figure through which a demystifying and interrogatory performance of both "femininity" and "maternity" takes place. At the heart of my argument lies the spectral violence that follows Kattrin through the play, the violence which defiles her before the drama begins, marks her and re-marks her as defiled, disgraced, and undesireable as the narrative progresses. Kattrin is born of violence, but the buried story of her origins and her troubled attempts to transcend them energize her damaged body with extraordinary subversive potential. $^{5}$

As I reframe Kattrin under the banner of Diamond's gestic feminist criticism, I take my immediate cue from work done by Gay Gibson Cima and Alisa Solomon on Good Person of Szechuan. ${ }^{6}$ Cima's provocative reading of the play in Performing Women (1993) suggests that in performance the doubly-gendered Shen Te functions not to reinforce basic gender differences of passive/helpless/feminine versus powerful/masculine, but actually subverts such polarities by 
dramatizing the "untenability" of an either/or paradigm (95). ${ }^{7}$ Alisa Solomon's "Materialist Girl: The Good Person of Szechwan and Making Gender Strange" (1994), ${ }^{8}$ follows Cima's lead (although Solomon ultimately rejects Cima's reading) as it more forcefully engages Diamond's critical program at the latter's own frontier. Solomon reads Shen Te's self-consciously theatrical transformation into Shui Ta as evidence of the play's inherent concern with the performative processes through which gender identity is produced and disseminated. She argues that the play's epic framework demands that spectators read both of the title character's incarnations - Shen Te and Shui Ta, masculine and feminine - "as inventions" (92), an implicit recognition of "gender's artificiality" (73), and thus an implicit critique of prevailing sexual ideologies, however simplistic Brecht's own investment in those ideologies may at first seem.

Cima and Solomon's readings suggest that Brecht's consistent dramatic investment in gender stereotype needs to be re-viewed as precisely that which makes gender's defamiliarization both potent and possible in his plays. The epic economy relies upon the constant interplay between performers, stage space, written/spoken text and audience engagement in order to throw the meanings localized in any single theatrical sign system into question; ${ }^{9}$ steeped in the selfreflexivity of Verfremdung, the plays build an interrogation of the processes of their own production into their representational schema, always demanding a certain skepticism toward the conventions they invoke. To dismiss Brecht's invocation of gender type(s) as a kind of uncritical perpetuation of those types may finally be, as Solomon suggests, to fail fully to understand the implications of epic technique for Brecht's female characters in performance.

\section{Abjecting Kattrin}


Mother Courage and her children have traditionally gotten mixed reviews from feminist critics. Some, like Lennox, Iris Smith, and Sarah Bryant-Bertail see little to salvage, arguing that the play offers yet another example of Brecht's use of female characters as “demonstration objects" (Lennox 84); his Marxist politics, they argue, are written across women's bodies, “the favorite medium through which ideologies are displayed, disguised and appropriated" in the Brecht canon (Bryant-Bertail 45). When they do admit the possibility of subversive feminist potential in the play, they are careful to note that such subversion can only surface against Brecht's own best intentions. ${ }^{10}$ Other scholars are somewhat more willing to credit Brecht with this subversion. Laureen Nussbaum argues that the play's mother figure is not Mother Courage herself but the childless Kattrin, anticipating arguments such as those of Kathleen Komar and Claire Gleitman, who locate the play's latent feminist potential in its deconstruction of the myth of traditional motherly virtues as they are radically rejected by Courage. Roland Barthes places this problematization into a specifically materialist context. Far from essentializing motherhood, he argues, Brecht locates it among the play's specific economies: "The indissolubility of business and motherhood in Mother Courage is an essential fact" (47).

While Brecht's intentions toward the proto-feminist Courage stirs debate, consensus is much more easily reached on the question of Kattrin, against whom feminist readings of Mother Courage tend to flounder. Naive, sentimental, self-sacrificing, and excessively fond of children, Kattrin is either cast as proof of Brecht's notorious gender blindness (the quintessential representation of what Lennox calls Brecht's “child-woman" [86]), read as her mother's foil and "bad conscience” (Nussbaum 233), or disparaged for spoiling the play’s otherwise-interrogatory stance on motherhood by reinstating maternal sacrifice as its privileged virtue in its final scenes (Lug 10; for a slightly different perspective, see Gleitman 164). 
The problem with many of these readings of Kattrin is the readiness with which they interiorize the traits she represents. Despite Brecht's ardent materialism and his insistent striving against a mythic human nature, critics imagine Kattrin to be a kind of epic anomaly, embodying innocence and instinct rather than "chaf[ing]," to borrow Gleitman's term (164), against these very traits. ${ }^{11}$ Though valuable in their questioning of Kattrin's perceived sentimentality, these readings finally miss its deepest implications as they gloss over the complex position the voiceless Kattrin inhabits within the play's dramatic economy - a position that demands she stand at all times in dialectical relation to her own attitudes and actions. In making this contention I am not simply reading epic acting technique back into an otherwise bland or troubling representation: rather, I would insist that epic acting is always already at stake for Kattrin, precisely because she cannot speak, because any attempts she makes at communication and self-actualization can only be carried out in gesture. Kattrin, in other words, operates exclusively within the privileged sign-system of epic, gestic theatre. A mute girl trapped in a warravaged universe that privileges quick wit and fast talk, Kattrin lacks the most basic tools of survival . But on a metatheatrical level, she also quite visibly (audibly) lacks the primary tool of stage realism: the voice as source of identity, the word as guarantor of the real. This is not to say that every sign she makes is necessarily a gestus,${ }^{12}$ I would argue, however, that every sign she makes is gestically potent, ripe with the possibility of signing against the representations she is assigned, of foregrounding their status as assignation. Not privileged to be the subject of discourse, she is quite plainly positioned by it, and is (in the best tradition of the epic stage) shown to be its product as she moves through the play adopting the labels given her by other characters and reproducing them on her body. Kattrin is not the radical failure of 
Verfremdungseffekt, but rather its embodiment, for to play Kattrin is necessarily to play against the text, to play with the radical deconstructive potential of gestic acting.

Kattrin's absolute reliance on gesture grants her semiotic privilege within the epic economy, but it also marks her as abject, in Julia Kristeva's sense of the term. In Powers of Horror, Kristeva defines the abject as that which we (violently) reject in order to constitute ourselves as discrete, differentiated, socially visible (viable) subjects. We vomit the abject in a visceral attempt to establish our interiority (2-3); our culture expunges it as it defines social categories and erects social limits. It is "the mode by which Others become shit" (Butler, Gender Trouble 134). Kattrin is Mother Courage's shit. Her silence is not simply a matter of dramatic convenience: it is the lasting (though largely invisible) mark of an oral rape by a soldier that takes place prior to the play's first scene, ${ }^{13}$ the insistent signifier of a defilement which has left Kattrin both sexually radicalized and socially marginalized. A monstrous vagina ${ }^{14}$ where her voice used to be, a phallic mother without a baby, Kattrin has been bereft of marriage prospects by this and at least two subsequent violations. She is good for nothing but falling into (sexual) danger, as Courage constantly reminds her. She is considered a disgrace to her gender, a failure as a woman. She moves through the play as a body called damaged, stupid and animal-like (MC 29, 34), a sight from which eyes would prefer to turn (74). To her mother, who calls her "nowt" (16), she is literally unspeakable, a walking wound that cannot be admitted to consciousness.

Kattrin's experiences of physical violence prior to her death in scene eleven mark another critical lacuna in the scholarly reception of this play, but my reading of them as unequivocally sexual in nature of course begs the question of their ambiguous representation in Brecht's narrative. The text's own ambivalence toward them suggests, I believe, just how fraught they are, how central they are to understanding the play's mother-daughter relationship, its interrogation of 
the strictures of maternity, and its construction of Kattrin's silent abjection as a function of her mother's often tremulous subjectivity. Toward the end of scene six, after Kattrin returns from town with a suspicious scar on her brow, we learn from Mother Courage of two previous incidents - the initial oral rape, as well as another occasion, later on, when Kattrin "stayed out all night" (58) and behaved oddly upon her return. Neither incident is described by Courage in any detail, for details about them are exactly what Courage lacks. They could be anything, or nothing: they cry out for our interpretation. Unseen by the audience (or indeed by any other figure in the narrative) and burdened by the tangible weight of their unspoken details, these events hang in the air like poison. Kattrin, for lack of voice, is unable to tell anyone what has happened to her; like Shakespeare's Lavinia, she becomes in her tonguelessness the product of others' preferred readings, reflections of their needs. Courage, in addition to being the play's primary source of information about Kattrin, maintains with her daughter the same difficult relationship she cultivates with the war. Battle has given Courage certain independence; she is free to cross national borders without proper papers while trailing three children, none of whom share a common father. But battle has also, it seems, marked its mundane cruelties on the body of her daughter; while Courage moves without restriction, Kattrin's options for happiness are more and more greatly circumscribed as the cart plows along. She embodies the war's substructure of sex (rape, prostitution) and violence, its ability to ruin a girl just as it affords an older woman limited freedoms. Courage's liberty marks Kattrin's endangerment, and, as is the case with everything related to the war's vulture-like quality, Courage's ability to admit as much is limited. Could it be that comprehending Kattrin's strange, mute suffering as the product of (repeated) sexual violation is simply a point to which Courage cannot permit herself to go - in other words, could it be exactly the point to which Brecht hopes we as readers and viewers will go in reading 
Courage's often hypocritical relationship to the war, and her troubled relationship to her own status as a mother?

Central to the play's dramatic economy yet banished by its Symbolic order, epic yet abject, Kattrin is a contradiction in terms - the very terms of identification, the very terms of performance. But, of course, contradiction is a commodity on Brecht's stage, just as it is in Kristeva's theory. Paradox and contradiction are the prime movers of the abject, which is, one might say, epic in its own relationship to the psycho-social processes of subject-formation. It is the quintessential boundary phenomenon: expelled from the social, the abject is functionally necessary to it. The abject establishes social categories as a function of its own continuous threat: menacing the social from its position on the tenuously constructed border between self/same/pure and unclean/impure/other, the abject "is neither banished nor cut off, it is thrust away but within - right there, working, constitutive" (Powers of Horror 106). Returning to Brecht's scene with Kristeva in the wings, we might modify my earlier claim that Kattrin represents the epicentre of the play's gender critique by noting that her very abject status guarantees this centrality. Violated, muted, scarred, smeared with dirt, degraded in discourse to nothingness, Kattrin embodies "the mythical defilement" that Kristeva argues "situates impurity" above all "within the mother woman" (83), but she also therefore necessarily operates on the margins of discourse where the categories "mother" and "woman" are both established and threatened. Kattrin lives on the border between sexual monstrosity and normative gender identification; desperate to overcome her debasement and attain a certain degree of social legitimacy, Kattrin spends the play trying to gender herself by mimicking the various forms of accepted feminine behaviour she witnesses around her. ${ }^{15}$ On the outside looking in, she can only echo gender norms in an attempt to construct herself in relation to that discourse of proper femininity which purports to expel her in 
the very moment it interpellates her as its limit. As she fails again and again to "do" her gender properly (Butler, "Performative Acts" 276) ${ }^{16}$ — to escape her wretchedness, to avoid violent rehearsals of the act which originally ruined her, to get (steal, snatch, never deliver) a baby — she becomes the "not-but," the centerpiece of the play's dramatization of the material processes of gender constitution. Further, as she collects babies in her attempts to cross over from the psychosocial hinterland to which she has been relegated, she performs a series of gests which explore the essential (though often silenced) interplay between symbolic abjection and conformist social role-play in the production of proper maternal bodies; her surrogate investment in the maternal ideal thus becomes an interrogation of motherhood's hidden abject origins. Seemingly "outside" femininity, beyond maternal possibility, Kattrin problematizes the categories in her very failure to get inside them. Put another way, if Mother Courage is meant to be the star (or "demonstration object") of a Marxist parable, Kattrin turns her mother's play into a parable of gendered identity production.

\section{Performing the Feminine, Demystifying the Maternal}

[D]esire, if it dawns, is only a substitute for adaptation to a social norm (is desire ever anything else but desire for an idealized norm, the norm of the Other?).

Kristeva, Powers of Horror 47

Much has been made of Kattrin's penchant for rescuing endangered children (scene five, scene eleven). Far from standing as irrevocable proof of Brecht's indulgence in an unproblematized maternal stereotype, however, these acts accrue critical significance in their repetitive nature. Judith Butler has argued forcefully that gender itself is the product of no less than repetition — "an identity instituted through a stylized repetition of acts" ("Performative Acts" 270, emphasis in original) - a product made believable precisely because it is enacted over 
and over again, and enacted each time as though for the first time. Reading Kattrin with Butler in mind, her endless repetition of the maternal rescue scenario becomes evidence of something far more complex than instinct.

Why does Kattrin want a baby so desperately? Brecht's emphasis on the iterative quality of her actions throws necessary critical light upon this too easily dismissed question, one which begs a critical correlative: what, specifically, does Kattrin desire? Scholarship on the play has tended to ignore both questions, taking the answer as a given with which to condemn Brecht's representation of the character, but critics who interiorize Kattrin's desire forget that she hardly manifests a "healthy," "maternal" love of babies; rather, she manifests an anxious, even neurotic desire to possess them. With this ownership angst in mind, perhaps we might more productively read her want of a child in light of the comments from Kristeva I cite above. Following Lacan, Kristeva reads desire as no less than the desire for another's desire, which is always a substitute in the search for something else entirely — for one's own desirability, for legitimacy, for a speaking position within the Symbolic order. ${ }^{17}$ As a mute, Kattrin is quite literally shut out of the latter; violated and forlorn, the social legitimacy which marriage brings is also seemingly beyond her reach. Roads are closed to her; all roads, it seems, but one. Kattrin, I am suggesting, desires not a baby as such, but rather the sanction which she recognizes babies can bring, the viable, socially-recognized position children offer women, a position from which she might become a woman, from which she might speak and be heard.

Where is Brecht, relative to Kattrin's desire? He is careful to remind us that her act of salvation in scene five is no less than yet another citation of the sentimental script of maternity which she has been desperately rehearsing for some time. Kattrin dashes into a shell-shocked house to save a child; Mother Courage complains that this seemingly impromptu act has yielded 
yet "another baby to cart around," an annoying reminiscence of the "last time" Kattrin played the self-sacrificing mother figure $(49,50)$. Brecht's production notes for the scene are telling: "[Angelica Hurwicz, who originally played Kattrin] carried the baby out of the house like a thief; at the end of the scene she lifted the baby up in the air [...] If her mother's share in the spoils is the fur coat, hers is the baby" ("Mother Courage Model"124-5). For Brecht, Kattrin's theft of the baby manifests neither instinct nor, crucially, motherly selflessness, but rather its opposite - a primary concern for the baby as material object, as an object of exchange in Barthes' maternal economy. For Kattrin a child represents the opportunity to be a care-giver and thereby to represent herself as a mother, opening the door to the "spoils" of legitimacy reserved expressly for women who become mothers.

Of course, Brecht's implicit alignment of Kattrin's and Courage's motives in scene five doesn't acknowledge, nor quite erase, the fact that it is but one of several moments during the play when Kattrin's maternal inclinations are deliberately contrasted against Courage's often shocking refusal to play the mother. Courage appears to lack maternal sentiment at exactly those moments when such sentiment might offer both herself and her children comfort; in response, Kattrin fills the blank, determined to provide succour to children in need wherever she finds them (scene five; scene eleven). In other words, against my reading of Kattrin's material instincts, one could easily argue that Brecht's contrasting characterizations are designed to make Courage and Kattrin into critical opposites, that Courage's social Darwinism sets Kattrin's delicate sensibilities into relief, highlighting them as fundamentally more humane, perhaps even more socialist, options on which to model one's own behaviour.

Yet Brecht's own notes on the play suggest a more compelling angle from which to view Courage's relationship to Kattrin as they offer an interpretation geared more toward complex 
comparison than simple contrast. Rather than reading the two characters as polar opposites in a capitalist/socialist demonstration model, and rather than reading Courage's ruthlessness as a screen projecting a re-sentimentalized and retrograde Kattrin back upon us, we need to take note of the striking ambivalence that marks all Courage's interactions with her daughter. I suggested above that Courage is unable to name the violence Kattrin has suffered; nevertheless, it surfaces for her again and again in her abiding terror that Kattrin will fall prey to sexual assault (see, for example, scene three, as Courage smears Kattrin's face with dirt to ward off rapists). She is forever impatient with Kattrin, the first to demean and degrade her, yet when offered the chance to abandon her for good in scene nine she refuses. Courage is cagey about the details of Kattrin's history and seems genuinely bewildered by her suffering; Kattrin, it seems, is her mystery. Is the troubling uncertainty that surrounds Kattrin indeed a foil to Courage's total commitment to the sale, a reminder of the moments in which the sale fails to suffice? Perhaps, but she is also more: she represents all those things - sexual vulnerability, reliance upon marriage and children for social sanction, an almost cavalier generosity - which threaten Courage, which remind her constantly of the risks she takes in re-writing her own social script, of the possibility all her earned independence might simply slip away, leaving her trapped once more by convention. Kattrin is above all Courage's abject, the spectral other who guarantees but also menaces her mother's unconventional self-determination; she is both essential (hence Courage will not leave her behind at the Cook's behest), and essentially nothing, in Courage's eyes. ${ }^{18}$ She is kept around to be kept down, as Courage fashions from her psychic fearsomeness a constant reminder of her own social and economic superiority, the downcast face smeared with dirt (29) that sets off Courage's ruddy power. Courage's relationship with Kattrin is at every turn its own contradiction, at once loving and loathing, the means by which the play constructs Kattrin not just as a "better" 
(because more conventional) mother but also as more and more literally abject; their relationship, in other words, is the ground on which the play sows the seeds of its interrogation of the covert yet fundamental connection between maternity and abjection - a connection which becomes the direct object of performative critique in scene eleven.

Just as Courage's seeming failure as a mother is never simple, Kattrin's behaviour toward her own adopted charges is never simply sentimental; mired in the logic of possession, Kattrin's gestures of care take on a superficial sentimentality, but are fundamentally hostile to maternal convention. I do not mean to suggest by this that Kattrin is a bad surrogate mother born of bad mothering; rather, I am suggesting that the play asks us to read, via both Courage and Kattrin, beyond the sentimental surface of Kattrin's supposed maternal idealism to a depth problem with the construction of that idealism itself. Beneath the simple tale of a mother who cares for her daughter only as an afterthought and the daughter who, in turn, becomes an over-cautious mother the play offers another, darker story, a story of origins that exposes the source of the so-called maternal ideal in acts of consistent degradation. Courage will not be a mother because to be a mother, she knows, too often means marginalizing one's own needs, bringing one's self low; Kattrin, who is consistently brought low - by violence, by circumstance, by her mother's own interpellations - seeks relief by selecting what is, the play suggests, an entirely appropriate occupation.

A play of tableaux, Mother Courage and Her Children needs to be read as a series of scenes which dialectically inform one another. The precedent for my reading of Kattrin's maternal materialism in scene five can be found in scene three, in which she is confronted by the chaplain, who demonstrates a sexual interest in her. Immediately thereafter, she becomes fixated upon the prostitute Yvette's hat and boots. During the following two pages of dialogue, Kattrin 
dresses herself in Yvette's clothes and begins "strutting around in imitation of her way of walking" (27, emphasis in original). This self-conscious performance, produced on stage in full view of the audience, makes a critical parallel with the onstage transformation of Shen Te into Shui Ta in Good Person, a moment which Solomon describes as offering "important clues about epic acting, the relationship between gender and epic acting, and indeed about gender $a$ s epic acting" (73, emphasis in original). Kattrin does not merely "try on" Yvette's clothes; she tries out the entire role which the audience has come to read as "Yvette." ${ }^{19}$ Added to this equation must be the variable of epic acting style, demanding a self-conscious performance which demonstrates rather than inhabits role. The result is an actor-character dynamic in which performer shows Kattrin showing Yvette, producing a chain of theatrical citations which in effect stages citation as the process by which identity is produced - in this case, the identity of the prostitute, the only recipient of sexual attention to which the abjected Kattrin can actively relate as "feminine." On yet another level, Kattrin's role-play stands as evidence of the overwhelming power of discursive interpellation: having been sexualized by the chaplain's address, Kattrin brings his words to life by literally playing the whore.

Kattrin carries the trace of this earlier performance with her into scene five, where it resonates against her "act" of maternal salvation. Sexually marked by her previous playing, Kattrin loads the space of the mother with the sign of the whore; she also brings with her the memory of her dirt-smeared face, the residue of Courage's anxious reaction to her performative strutting and fretting. If Kattrin plays the mother in this scene, she does so from a position of defilement rather than empowerment; she is less an ideal mother than an abject mother, is (insofar as her performance is successful) a little bit of both, an epic representation of the confluence of these two identifications. I will examine this characterization of Kattrin in detail 
below; for now, I want to emphasize that Kattrin's earlier performance also, crucially, echoes in scene five as the trace of iteration, of performative citation, of identificatory role-play. Kattrin's scene three attempt to perform herself in relation to the (socially powerful, fiscally successful) Yvette is above all an attempt to enter the play's normative gender economy (of which Yvette, given the chaotic wartime frame, forms the nexus), one which I would argue establishes a critical framework through which we may read all of Kattrin's subsequent actions. As we view the rescue scenario in scene five through the lens of scene three's meta-performance, Kattrin's hypervigilance towards the stranded baby need no longer appear a function of instinct, nor even a function of (dysfunctional) socialization, but rather as a more or less conscious effort to gender herself by maternalizing herself (over and over again). Kattrin's attempt to naturalize herself as Kristeva's "mother woman" simply by "find[ing] a baby" ("Mother Courage Model" 122) exposes the radical dependence of the "feminine" on the prior interpellation of all women as mothers in waiting, and explodes the myth of her supposed maternal interiority by revealing the material process of and impetus for its generation. Neither instinctual sentiment nor physical function will make her a mother, but simply the presence of a dependent body, the gestures of seeking it, holding it, lulling it, crying for it - and, of course, dying for it.

\section{Maternity and the Discourse of Sacrifice: Re-reading Kattrin's Big Scene}

Sacrifice $[\ldots]$ operates between two heterogenous, incompatible, forever irreconcilable terms [the abject and the sacred]. It connects them necessarily in violent fashion, violating at the same time as it posits $[\ldots]$ the semantic isotopy of each.

Kristeva, Powers of Horror 95

By the time Kattrin and Mother Courage arrive at Halle in scene eleven, Kattrin has been left with a scar (her souvenir from another [attempted?] violation, in scene six); she is now 
visibly (as well as audibly) detritus, and her psychic shame shows as she prefers to hide its mark under an old blanket. In this state of utter abomination, Kattrin martyrs herself to the children of the town.

Oversimplifying Kattrin's act of sacrifice is fraught with pitfalls, for sacrifice is no simple act. In biblical tradition, as Kristeva notes,${ }^{20}$ sacrifice is the very act which establishes and authorizes the sacred, and thereby, like all acts of abjection, threatens radically to disturb the very order it enforces: in destroying itself, sacrifice renders momentarily visible the sacred's dependence upon it. By the time Kattrin appears up on the roof in scene eleven, she has already been repeatedly characterized as both abject and maternal; in Halle, these two inscriptions collide with force as Kattrin's self-abrogation produces Western patriarchy's sacred self-sacrificing mother figure in the moment of its apotheosis. Kattrin sacrifices herself not just to the children of Halle, but also to the maternal ideal; in effect, she exposes the "mother woman" as sacrifice, as always already a function of abjection.

Readings of this scene which condemn Brecht for naturalizing Kattrin's actions ${ }^{21}$ tend to miss its performative component — a significant elision, considering that Kattrin's self-sacrifice is perhaps the play's single most impressive performance, a drum solo designed, like all Brechtian performances, to incite action. But the gest of drumming to wake the town to the threat of impending siege is preceded by another extraordinary potent(ial) gest. Hearing from the old peasant's wife that children are in danger in the town below, Kattrin "slip[s] away to the cart and [takes] from it something which she hides beneath her apron; then she climbs up the ladder on to the stable roof' (83, emphasis in original). Following this stage direction, the peasant's wife utters a brief supplication to "Forget not the children, what are in danger," the peasant recites the final lines of the Lord's prayer, and then Kattrin "begins to beat the drum which she 
has pulled out from under her apron" (83, emphasis in original). Up on the roof, on her own stage at last, Kattrin gives birth to the drum. ${ }^{22}$

Visually stunning, this act renders the birth moment overtly performative - it is a gest which lends what is normally imagined as a purely biological function an important dimension of social iteration. This is a moment that an actor playing Kattrin, having already demonstrated the specific materiality of her character's obsessive desire to become a mother during the rescue scenario in scene five, can and should emphasize and enjoy on stage. Pulling something large and fully formed from under her clothes, Kattrin alludes not to actual, physical labour, but more immediately to backyard games in which little girls practice playing Mommy by giving birth to everything from dolls to pillows. Beating out her warning of impending attack, Kattrin references the discourse of maternity through which little girls are gendered, as they are invited to internalize the regulatory script of normative heterosexuality which interpellates them into girlhood only by anticipating their eventual motherhood. ${ }^{23}$ As she performs this birth which both is and is not "real," Kattrin ironically exposes even her "failed" woman's body as a discursive field across which the expectation of inevitable impregnation has been indelibly scrawled.

The drum, of course, is not just Kattrin's baby (the only one, finally, that can grant her a voice); it is also invocation, provocation, a warning to Halle to rise and fight, and a warning to the audience to do the same. In terms characteristic of Brecht's politics, it represents a challenge to capitulation and a refusal to be daunted by the destructive weight of wartime status quos; for Brechtian feminists, however, its resonance sounds on a different level. Kattrin knows as she drums that she will be killed for so doing; in birthing the drum as a surrogate voice, Kattrin literally births her own sacrifice, performing the birthing process as inseparable from the act of sacrifice. Having already de-biologized this process by locating the allure of its physicality within 
popular myth and play, the play now lays bare the radical dependence of sentimental maternity upon the discourse of sacrifice. In order to become patriarchy's sacred mother figure, a woman must first be willing to die for her baby; that is, she must first be willing to negate herself, to acquiesce to Courage's abjecting abuses, to Kattrin's now-sacred "nothing"ness in order to become something, someone in the eyes of culture. ${ }^{24}$ Kattrin does not die for her baby; rather, she dies by her baby for an entire village of babies, finally achieving the social ideality she has spent the play seeking only by yielding herself up to its symbolic lack-in-being. The ensign who promises not to hurt her own mother if she will only stop drumming is shocked to discover his promise has on Kattrin the opposite of the desired effect. Demanding "[i]s nothing sacred to her?'(84), he makes an ironic and revealing counterpoint to the gest of Kattrin's drumming, for the sacred in this moment is indeed "nothing" - or, rather, is the contradictory act of sacrifice itself, delivering Kattrin from her social and psychic abomination only by laying waste to her body.

As Kattrin dies at the hands of enemy soldiers, the play rehearses most lucidly and for the last time the scene of her abject origin. ${ }^{25}$ In this late moment of shockingly visible brutality, we cannot forget — indeed, I want to suggest that we are forced to remember — that Kattrin's primal scene has remained unstaged, and, with the exception of an opaque reference, unspoken. The invisible act which marks Kattrin's entry into culture makes her forcibly and often uncomfortably visible to the world, but remains itself hidden in the fissures of Courage's — and history's - selective memory. This final act, however, is repetition with difference: this time around, Kattrin is the author, not the object, of the scene, and this time, rather than muteness, its principle consequence is an exceedingly public form of expression. I do not mean here to suggest that Kattrin has at last "found a voice" in the manner of the sentimental heroine; rather, I would 
argue that this voice — in the best tradition of the epic theatre - expresses its opposite: the silence with which her various violations and defilements have been greeted throughout the play. Kattrin's drumming marks at last the exposure of the covert discourse of violence-asidentification which the play chronicles; as she invites the soldiers' fire she demands as well a critical revisiting of the scene of her initial violation, one which can finally account for all the players, and all the consequences. Kattrin trumps the soldiers: they do not want to kill her, yet they do because not to kill her would amount to a failure, on their part, to be soldiers. As they fuss and argue over what to do in the face of a woman they cannot intimidate, the source of their soldierly authority — in effect, of the masculine authority of war — becomes rather painfully clear: it is Kattrin, the abject mute on the roof with a small drum, on whom their identities as fighting men (and the authority of the regimes they uphold) ultimately depend.

Kattrin ends the play as a corpse, that which for Kristeva represents the mythic fear of the abject mother, and that which for Valerie Traub represents the radical destabilization of bodily and psychic boundaries. The dead are "fundamental pollution" (Powers of Horror 109), and as such they inhabit the full force of abjection's subversive power: dead bodies can only with difficulty be sexed and gendered, for in the decay of post mortem, as Traub argues, the ruse of essence becomes grotesquely palpable. Hence burial becomes "a means of purification" (Powers of Horror 109), the embalming process an anxious attempt to preserve the imagined interiority of an identity written, in life, across the body. Within this critical framework, the specific gests of showing Kattrin's death and displaying Kattrin's corpse on stage through to the end of the play become both relevant and necessary to a feminist reading. As a (muted) body in life, Kattrin is seemingly a sign to be written and read; as a corpse, however, her body resists simple reading. ${ }^{26}$ Mother Courage's final lullaby attempts to infantilize Kattrin one last time, but that 
infantilization resonates ironically against the derealization of conventional mother-child relations which Kattrin's actions in scene eleven accomplish. Kattrin, finally, ends divested. ${ }^{27}$ The silence which throughout the play marks both her concomitant insufficiency in and her diacritical stance toward the processes of normative gender identification becomes in these final moments the expression of the radical insufficiency of such identification, as it fails to contain her body on the cusp of disintegration.

My reading of Kattrin's materialist potential has relied very much upon my vision of her as an epic actor (and on the epic acting skills of any performer who might take on the role), and I have come to realize through various drafts of this essay that I have been imagining an idealized, perhaps at times idealistic, feminist performance of this play centred on Kattrin as a feminist performance artist. While I have been thinking and re-thinking the nuances of her role, I have become increasingly aware of the gap that inevitably opens up between the ideals of criticism and the realities of practice. We might well ask whether the critical matrix of abject mother - turned - subversive gender performer within which I have located Kattrin can so easily translate into performance space, so easily be made a successful counterpoint to a simpler, more sentimental reading of the conventional actions and reactions that flesh out her representation, especially as contemporary America continues its fascination with "family values." I would argue that surely, yes, given the right company at the right moment, in front of the right audience, the complexities Kattrin embodies need not remain buried; Brecht's own theory calls for a complexity of representation that feminist performers around the world have adopted, edited, and made their own. The apparatus of production - including media interviews with cast, director, designers and dramaturgs, promotional material, and program notes - can be and often is used to fill in theoretical and historical gaps where producers see fit, augmenting the performance with a 
context not all audience members may bring to the viewing experience, but which many may welcome. Alternately, we might place the hope of a newly radical representation of Kattrin in what Jill Dolan calls the "utopian" space of rehearsal, the place where, despite the very real possibility of failure, lovers of theatre never stop trying to get it right, never stop trying to achieve the "magic" of a moment communicated, understood, shared, debated, even against the odds (458). Idealism, as Kattrin so stridently demonstrates, can be a dangerous thing indeed, but it also, I believe, powers our best criticism, and our best art.

\section{Works Cited}

Barthes, Roland. "Seven Photo Models of Mother Courage.” TDR 12.1 (1967): 44-55.

Brecht, Bertolt. Brecht on Theatre. Ed. and Trans. John Willett. New York: Hill and Wang, 1964.

-----. "Mother Courage and Her Children.” Collected Plays. Vol. 5.2. Ed. John Willett and Ralph Manheim. Trans. John Willett. London: Methuen, 1980. 1-88.

-----. “The Mother Courage Model.” Brecht, Collected Plays 96-144.

Bryant-Bertail, Sarah. "Women, Space, Ideology: Mutter Courage und ihre Kinder." Brecht Yearbook 12 (1985): 43-61.

Butler, Judith. Bodies That Matter: On The Discursive Limits of 'Sex.' New York and London: Routledge, 1993.

-----. Gender Trouble: Feminism and the Subversion of Identity. New York and London: Routledge, 1990.

-----. "Performative Acts and Gender Constitution: An Essay in Phenomenology and Feminist Theory." Case 270-82.

Case, Sue-Ellen. "Brecht and Women: Homosexuality and the Mother. Brecht Yearbook 12 (1985): 65-74.

-----, ed. Performing Feminisms: Feminist Critical Theory and Theatre. Baltimore: Johns Hopkins UP, 1990. 
Cima, Gay Gibson. Performing Women: Female Characters, Male Playwrights, and the Modern Stage. Ithaca and London: Cornell UP, 1993.

Diamond, Elin. "Brechtian Theory/Feminist Theory: Toward a Gestic Feminist Criticism.” TDR 32.1 (1988): 82-94.

-----. “Mimesis, Mimicry, and the 'True-Real."” Modern Drama 32.1 (1989): 58-72.

Dolan, Jill. "Performance, Utopia, and the 'Utopian Performative."' Theatre Journal 53 (2001): 455-479.

Gleitman, Claire. "All in the Family: Mother Courage and the Ideology in the Gestus." Comparative Drama 25.2 (1991): 147-67.

Herrmann, Anne. "Travesty and Transgression: Transvesticism in Shakespeare, Brecht and Churchill." Case 294-315.

Komar, Kathleen L. "Paradigm Change: The Female Paradigm in Brecht's Mutter Courage und ihre Kinder and Christa Wolf's Kassandra." Euphorion 82 (1988): 116-26.

Kristeva, Julia. Powers of Horror: An Essay on Abjection. Trans. Leon S. Roudiez. New York: Columbia UP, 1982.

Lacan, Jacques. "The Meaning of the Phallus." Feminine Sexuality: Jacques Lacan and the École Freudienne. Ed. Juliet Mitchell and Jacqueline Rose. Trans. Jacqueline Rose. New York: Norton, 1985. 74-85.

Lennox, Sara. “Women in Brecht's Works.” New German Critique 14 (1978): 83-96.

Lug, Sieglinde. "The 'Good' Woman Demystified." Communications from the International Brecht Society 14.1 (1984): 3-16.

Nussbaum, Laureen. "The Evolution of the Feminine Principle in Brecht's Work: Beyond the Feminist Critique." German Studies Review 8.2 (1985): 217-44.

Reinelt, Janelle. "Rethinking Brecht: Deconstruction, Feminism, and the Politics of Form." Brecht Yearbook 15 (1990): 99-107.

Smith, Iris. "Brecht and the Mothers of the Epic Theater." Theatre Journal 43.4 (1991): 491-505.

Solomon, Alisa. Re-Dressing the Canon: Essays on Theater and Gender. New York and London: Routledge, 1997.

Stern, Guy. "Enriching Mother Courage." Communications from the International Brecht Society 25.1 (1996): 60-68. 
Traub, Valerie. "Gendering Mortality in Early Modern Anatomies.” Feminist Readings of Early Modern Culture: Emerging Subjects. Ed. Valerie Traub et al. Cambridge: CUP, 1996. 4492.

\author{
Varney, Denise. "Focus on the Body: Towards a Feminist Reading of Brecht in Performance." \\ Communications from the International Brecht Society 29.1-2 (June 2000): 29-39.
}

\title{
Wright, Elizabeth. "The Good Person of Szechwan: Discourse of a Masquerade." The Cambridge Companion to Brecht. Ed. Peter Thomson and Glendyr Sacks. Cambridge: CUP, 1994. 117-127.
}

\footnotetext{
${ }^{1}$ For their keen eyes and generous support during the preparation and editing of this article I would like to thank Nancy Copeland, Elizabeth Harvey, and Joanne Tompkins.

${ }^{2}$ See especially Reinelt.

${ }^{3}$ This is something that Diamond herself acknowledges at the outset of "Brechtian Theory."

${ }^{4}$ See Case, "Brecht and Women," Herrmann, Reinelt and Wright. Case's article, stimulating in its reading of several of the early plays, takes Brecht to task for casting the figure of the mother as a harbinger of conservative values, an asexual foil to his other, richer (generally male) representations of "desire and corporeality" (69). Herrmann's investigation of "travesty and transgression" in Good Person of Szechuan concurs with both Case and Lennox, and suggests that the Verfremdungseffekt always breaks down in Brecht's own work at the junction of socioeconomic critique and sexual relations. Wright is similarly skeptical of Good Person, arguing that the play's conventional use of Shen Te's masquerade as an object-lesson in Marxist critique is missing "an examination of the material conditions of gender behaviour outside its relation to class" (121). Reinelt, like Diamond principally interested in the value of Brechtian theory's contemporary potential, also like Diamond damns Brecht in the very process of praising (106). She insists that the "stance" of his theatre is "always adversarial vis-à-vis the prevailing hegemony" (99), but curiously does not extend this claim to include the patriarchal hegemonies manifest in his own plays.

${ }^{5}$ Although I will restrict my remarks, for the most part, to Kattrin, I am aware that my reading of her throws open the door to new and potentially exciting re-readings of Mother Courage herself. Courage has typically been examined through a Marxist lens; what might happen were we to shift focus, and align her with, say, Butler or Kristeva instead (or in addition)? Such an alignment is beyond my scope here, but not beyond my interest, and hopefully not beyond the interest of like-minded feminist critics.

${ }^{6}$ Good Person remains by far the most popular play for recent feminist scholarship, and has been the only one to receive serious attention from scholars interested in the gest of gender production in Brecht's dramatic work.

${ }^{7}$ Ironically, Cima's reading relies on something of a polarity of its own. She distinguishes, albeit with tremendous nuance, between Brecht and the "Brecht Collective" - those women (Hauptmann, Steffin, Berlau) whose dramatic labour for Brecht, she argues, has left a palpable trace in the later plays' concerns with "how the idea of woman and man are constructed" (95). Her notion - over and against conventional "intentional" readings of Brecht's female characters - that a radical gender critique may have found its way into the plays via the very gendered dialectic of their production, a dialectic which may now be explored through an active feminist engagement with Diamond's own prescriptions for epic feminist acting, directing, and reading, maps out exciting new ground for Brechtian-feminist relations.

${ }^{8}$ Reprinted in expanded form in Re-Dressing the Canon (1997). All my citations from Solomon have been taken from the latter source.

9 " [L] et us invite all the sister arts of the drama, not in order to create an 'integrated work of art' in which they all offer themselves up and are lost, but so that together with the drama they may further the common task in their different ways; and their relations with one another consist in this: that they lead to mutual alienation" (Brecht on Theatre 204, my emphasis).

${ }^{10}$ This is a relatively typical feminist response to Brecht, palpable in Cima's work on Good Person as well as in less sympathetic readings of that and other texts. For a recent example, see Denise Varney's "Focus on the Body," which examines a new production of Good Person using a phenomenological feminist critique. In contrast to Solomon's
} 
work on the text, with which she does not engage, Varney argues that only in "sidestepping" Brecht's own epic techniques can the play be "reinvigorat[ed] [...] through the politics and discourse of gender" (38).

${ }^{11}$ Protests against Kattrin's apparent sentimentality must be contextualized by both Brecht's detailed notes on the play and its stage history, which saw several revisions aimed at curbing audience empathy. "Conventional heroism must be avoided," writes Brecht of Kattrin's act before the town of Halle, noting that she is "ridden" by fear, and not instinct, and enabled not by her naivete or her dumbness, but by the material fact of the drum which the war has made available to her. "The whole point is missed," Brecht argues, if Kattrin's love of and actions toward children are "depreciated as mindless animal instinct. Her saving of the city of Halle is an intelligent act" ("The Mother Courage Model"138, 125).

${ }^{12}$ On the difference between gesture and gestus, see Brecht, Brecht on Theatre 104-5.

${ }^{13}$ This is described by Mother Courage at the end of scene six (59). All subsequent references to the play will appear in the text.

${ }^{14}$ I use this term to signal the horrifying humiliation, the physical and psychic sense of un-clean-ness, that is the byproduct of sexual violence for so many victims. Kattrin's mouth, place of language, nourishment, potential sexual pleasure, collapses into an image of sexual danger and bodily disgust once it has been made grotesque, terrifying, uncanny by violent oral contamination.

${ }^{15}$ On the critical value of mimicry, see Diamond, "Mimesis, Mimicry, and the 'True-Real."” Though Diamond's intertext in developing her theory of a feminist mimesis is Luce Irigaray's Speculum of the Other Woman (trans. 1985), her argument makes important parallels with Butler's notion of a subversive repetition (as a challenge to the insidious performative act) developed in Gender Trouble.

${ }^{16}$ I am not suggesting that the character Kattrin is conscious of this feminist Verfremdungseffekt; as Reinelt points out, Brecht's characters are not meant to be self-aware (103). Rather, it is the task of the epic actor to demonstrate character in its constitutive materiality - the actor playing Kattrin is the one ultimately responsible for making Kattrin's citations visible as such to the audience.

${ }^{17}$ See Lacan, "The Meaning of The Phallus," esp. 83-4.

${ }^{18}$ Courage's introduction of Kattrin to the Sergeant in scene 1 is telling: both Eilif and Swiss Cheese have paternal histories which Mother Courage eagerly recounts to the military stranger, but Kattrin warrants barely a mention, and has no father Courage is willing to acknowledge. As far as her mother is concerned, Kattrin is without a history. ${ }^{19}$ Brecht's notes on the scene reflect this emphasis: Kattrin walks "the same ground" that Yvette did moments before; her "pantomime" follows Yvette's own performance as carefully as possible ("Mother Courage Model" 116). ${ }^{20}$ Kristeva's discussion of sacrifice can be found primarily in Powers of Horror 90-112.

${ }^{21}$ Although Sarah Bryant-Bertail productively points to the link between Kattrin's facial disfigurement and her consignment to "the path of the martyr" (57), she also insists that the scene at Halle is evidence that "Brecht has not varied from the traditional didactic formula that specifies that a woman must be the sacrifice that redeems the society" (58). See also Lug.

${ }^{22}$ My thanks to my colleague Marlis Schweitzer for sharing her reading of this image with me.

${ }^{23}$ This is a variation on Judith Butler's reading of the moment of gender interpellation (Bodies That Matter 231-2).

${ }^{24}$ Mother Courage, of course, apparently refuses this contract on all counts, and her refusal has marked feminist interest in the play up until now. I find it compelling to wonder, though, if Courage doesn't make her own, perverse investment in maternal sacrifice as she "preps" her daughter for her final moment in the spotlight. She has, in effect, contracted the job out to Kattrin.

${ }^{25}$ It's no accident, I would argue, that the drum Kattrin beats in this scene is the same one she acquired on her fateful trip to town with the supposedly harmless clerk in scene six.

${ }^{26}$ Brecht's politics might suggest that the play's final tableau ought to be plainer in its meaning, and of course on one level Courage's final gestures of care - perhaps the only unambivalent ones she accomplishes in the play - are stunningly simple and moving, both critically and emotionally. I would also venture, however, that Brecht's dialectics leave room for ambiguity, for argument over the challenges to interpretation - both in this moment and in previous moments - which Kattrin's now completely silenced body poses.

${ }^{27}$ Guy Stern notes instructively that in several productions of the play Courage mourns Kattrin while simultaneously removing her clothes (63). 